\title{
Graptolite dynamics in Silurian and Devonian time
}

\author{
TATJANA N. KOREN'
}

Koren', T. N.: Graptolite dynamics in Silurian and Devonian time. Bull. geol. Soc. Denmark, vol. 35, pp. 149-159, Copenhagen, July 1st, 1987. https://doi.org/10.37570/bgsd-1986-35-16

\begin{abstract}
On the basis of biostratigraphic data known at present some preliminary attempts are made to evaluate graptolite dynamics, that is changes in graptolite diversity in time and space within pelagic facies of Silurian and Early Devonian age. For the comparative studies of diversity fluctuations versus some major environmental changes a standard graptolite zonation is used. Several critical and more or less well studied stratigraphical intervals are chosen; among them the Ordovician/Silurian, Sheinwoodian/Gorstian and Gorstian/Ludfordian boundary beds. For each level the most complete reference sections are analyzed. Special attention is given to the graptolite extinction, specification and radiation events within these time intervals. They might have been partly connected with or influenced by the environmental factors as a result of eustatic sea-level and climate changes, alteration of anoxic conditions, migration of carbonate sedimentation in pelagic direction, and other globally detectable events. The graptolite evolution during the time of monograptid existence can be subdivided into three phases using the comparison of the amplitude of the extinction-origination events and repeatability of the synphasic cycles.
\end{abstract}

T. N. Koren', A. P. Karpinsky All-Union Geological Research Institute, Sredny pr., 74, 199026 Leningrad, USSR. December 2nd, 1985.

\section{Introduction}

Graptolite dynamics, that is, changes in species diversity with time and space, are shown to occur in pelagic facies of Silurian and Devonian age. Some preliminary attempts are made here to envisage fluctuations in diversity versus some major environmental changes, discernible on a worldwide scale. During this time interval the relative abundance of graptolite taxa can be exemplified by two zones. Species numbered 40 to 60 for the triangulatus to turriculatus zones (Llandovery), when they flourished. And it decreased to four to five species before their final extinction in the $y u$ konensis Zone (the uppermost Pragian).

In general the Silurian and Devonian assemblages contain more than 400 species and subspecies. Most of them were of global distribution within the pelagic realm at equatorial and moderate palaeolatitudes. Synchronous zonal assemblages differ in diversity within the known regions, but a few taxa were found from one region only. The latter perhaps suggests some ecologically peculiar features within a certain basin. To a certain degree their limited distribution may, however, result from an inadequate sampling and incomplete studies.
A standard graptolite zonal succession for the Silurian and Lower Devonian (Koren 1984) is based on the graptolite occurrences from all the continents as well as a continuous biostratigraphical record and reliable regional zonations. At present there is no well-founded absolute time scale to measure duration of zones, though such attempts have been made on the basis of different approaches (Carter et al. 1980, Churkin et al. 1977, Harland et al. 1982). Graptolite zones are definitely of unequal duration, and, accordingly, one can not measure the speciation or extinction rate. All we can do is to analyse highs and lows in graptolite diversity per zone.

The above problem has previously been discussed in the literature for the entire time interval or for particular stratigraphic levels (Bulman 1964, 1971; Jaeger 1978; Rickards 1978; Koren 1979, 1982, 1983; Koren \& Rickards 1979) both on regional and global scale. As a result a general picture of the Silurian and Early Devonian graptolite diversity has been obtained. The present paper is aimed at preliminary recognition of graptolite dynamics at a zonal level using a synthesis of the data available and some new results. However, the author met with some difficulties. For example, the picture of phyletic evolution with the rare exceptions is quite vague. In this re- 
spect we refer to studies of triangulate monograptids by Sudbury (1958) and cucullo- and neocucullograptids by Urbanek (1966, 1970). Our knowledge of graptolite ecology, is the second weak point, though many interesting suggestions have been made in recent years (Berry 1973, 1979, 1984; Berry \& Boucot, 1972; Berry \& Wilde 1978, 1983; Erdtmann 1976; Kaljo 1978; Kirk 1969, 1972; Rickards 1975; Skevington 1974; Watkins \& Berry 1977). These include graptolite depth stratification, automobility and other aspects. It was briefly summarised in a recent paper by Lenz \& Chen (1985). One can not usually make a reconstruction of peculiar environmental features of the graptolite habitats on the basis of the sediment records which has successfully been shown for many benthic groups. Primarily we consider taphocoenoses not life communities. Besides the lithology of the typical graptolite-bearing rocks is fairly monotonous. Changes of environmental factors which have been critical for graptolite mass extinction and origination waves may not be reflected in lithoevents within pelagic sequences. They have to be searched for in the shelf direction.

We may conclude that graptolites inhabited the near surface pelagic environments, most probably they reached as far as mesopelagic water masses. It means that temperature gradient, nutrient supply (most probably phytoplankton) and biocoenotic relationships were the most important parameters responsible for graptolite ecological maxima and minima. The complex picture of abiotic changes which affected biotope facies is diagrammatically shown by Walliser $(1984 a, c)$. It is clear, that not a single causal mechanism triggered and stimulated the adaptive changes in graptolites. Evolutionary highs and lows via a long chain of actions and interactions have resulted from biotope transformations and deteriorations caused by plate tectonics, eustatical sealevel changes, as well as by climate fluctuations and oceanic current patterns. Physical-chemical parameters of water masses and land also contributed greatly to the development and productivity of oceanic plancton.

However, the absence of proper data and elaborate techniques prevent us from discussing those genetic relations between biotic and abiotic controls. Using available material we can only try to evaluate the graptolite dynamics for several stratigraphic intervals.

A generalized graptolite zonation is taken as a basis for comparative studies of successive graptolite diversity changes within the Silurian and Lower Devonian (Fig. 1). We take three particular stratigraphic examples indicative of a diversity pattern during the most important environmental changes. They coincide with the supernus to atavus, lundgreni to scanicus/chimaera and leintwardinensis to ultimus s.l. zones. Each interval is of about the same duration, 4 or 6 million years or less. The stratigraphical levels chosen were studied thoroughly partly because they incorporate the system, series and stage boundaries, recently discussed and defined by subcommission on Silurian stratigraphy (Holland 1984, 1985; Bassett 1985).

\section{Approach}

Three or four regions having the most complete and well known stratigraphic succession and faunal record were chosen to illustrate the graptolite dynamics. As a rule the mentioned sections are situated within facially different successions typical of slope zones of marginal cratonic seas and oceans. Frequency distribution curves are given for each region separately (Figs. 2-4). The column showing zonal assemblage structure summurizes biostratigraphic evidence for all the regional successions. It embraces species which appear within the unit, those surviving from the preceeding one, and taxa which disappear between the two zonal boundaries. For each zone the total number of taxa is given.

Mass extinctions and appearances are considered as the most important bioevents. The first is used to explain an abrupt elimination of several lineages, generic and specific groups of cryptogenic origin. The term appearance in this case has a broad meaning and incorporates events of origination of new lineages and splitting of surviving ones as well as radiation events. Asterisks show the introduction of adaptive novelties; their relative size implies a different taxonomic significance. Both extinctions and appearances resulting in well pronounced culminations and lows mark widely detectable zonal boundaries which could be considered as event boundaries. 


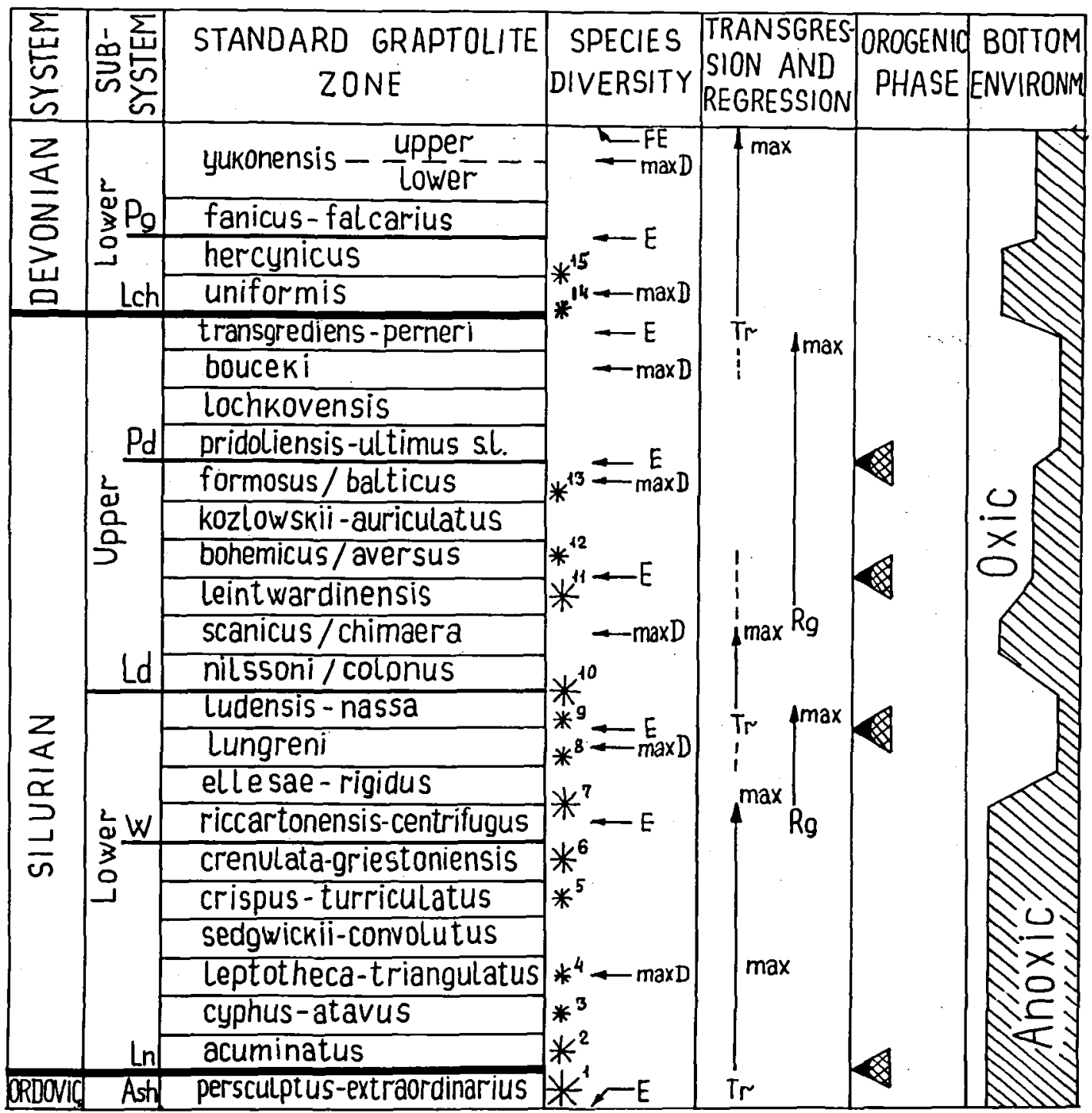

Fig. 1. Chart showing a generalised picture of graptolite dynamics against the major geological events in the Silurian-Early Devonian time. Abbreviations: E - extinction, $\mathrm{D}$-diversity, $\mathrm{Tr}$ - transgression, $\mathrm{Rg}$ - regression. Asterisks and their size show the introduction of the new adaptive novelties of different taxonomic significans. They are as following: 1 - Suborder Monograptina (Monograptus ceryx Rickards et Hutt, 1970); 2 - Family Dimorphograptidae (Akidograptus, Parakidograptus); 3 - radiation in the "stem" atavograptids: Přibylograptus, Lagarograptus, Coronograptus; appearance of Metaclimacograptus, Clinoclimacograptus, Rhaphidograptus; $4-$ radiation of the triangulate monograptids; appearance of Rastrites, Diversograptus, Petalograptus and other genera; 5 - Monoclimacis, Sinodiversograptus, the Retiolites geinitzianus, Monograptus priodon, M. spiralis and Pristiograptus dubius groups; 6 - Family Cyrtograptidae; 7 - new cyrtograptid lineages and the Plectograptinae Subfamily; 8 - cyrtograptid radiation; 9 - radiation within the Plectograptinae Subfamily and $P$. dubius group; an appearance of the common ancestor of the Linograptinae, Cucullograptinae and Neocucullograptinae Subfamilies; 10 - appearance of Neodiversograptus, Bohemograptus, Saetograptus and the Monograptus uncinatus group with subsequent radiation of newly formed stocks, including lobograptids in the scanicus/chimaera Zone; 11 - the Linograptinae Subfamily and new monograptids of the $M$. uncinatus group; 12 - Neolobograptus and Neocucullograptus; 13 - the Monograptus formosus group and several new monograptid lineages; 14 - the Monograptus uniformis and M. aequabilis groups; 15 - Abiesgraptus.

The diversity pattern shows the relative magnitude of extinctions, appearances and survivals plotted against some geological processes and events. Among them are eustatic sea-level and climate changes, alternation of anoxic and oxic environments and to some degree the Caledonic orogenic phases. 


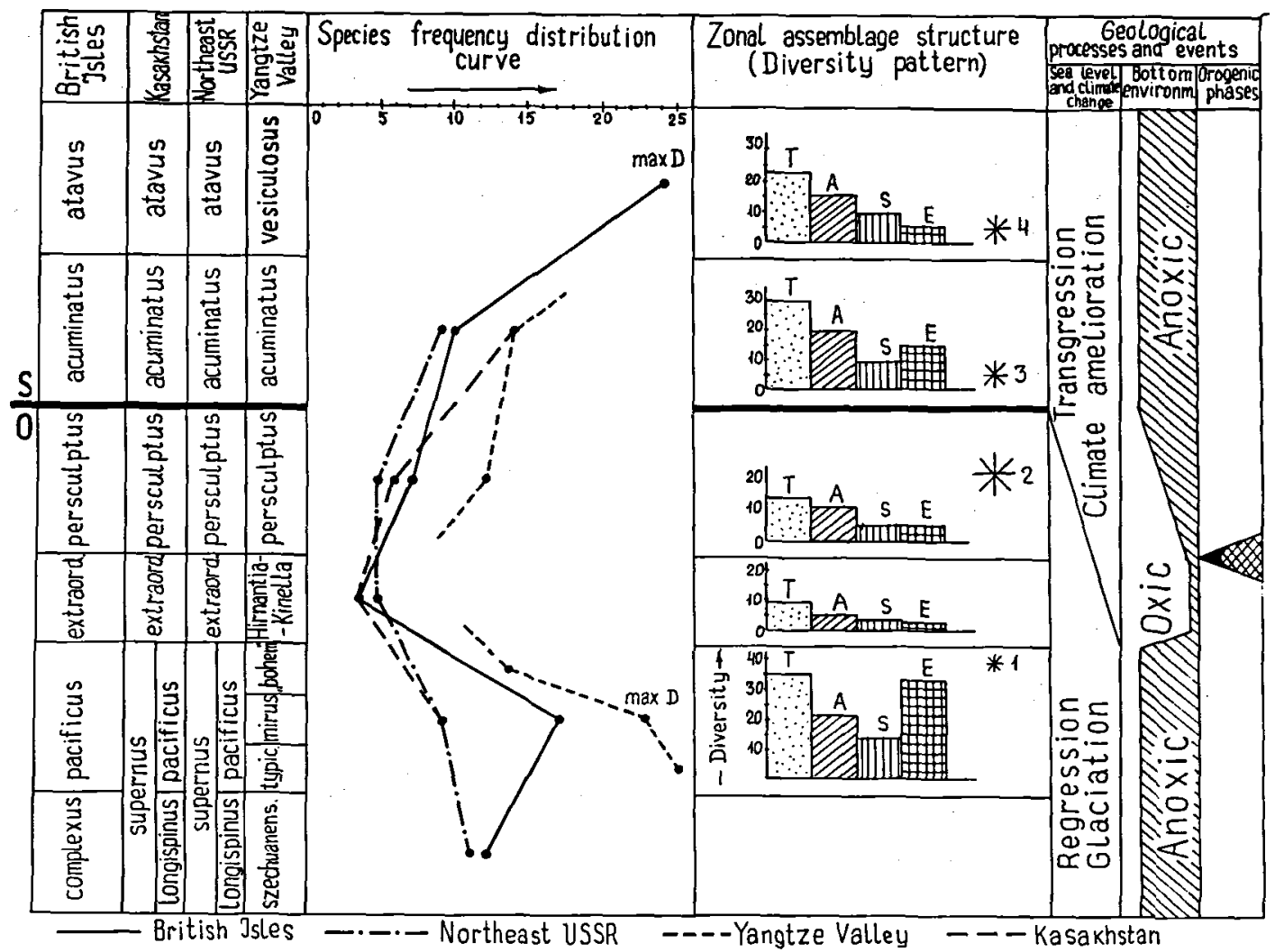

Fig. 2. Graptolite dynamics within the Ordovician-Silurian boundary interval (the supernus event). Abbreviations: D - diversity, A appearance, $\mathrm{S}$ - survivial, E - extinction, T-total number. Asterises show the following bioevents: 1 - mass extinction of the Ordovician lineages formed by the Dicranograptidae, Nemagraptidae and Lasiograptidae Families, the Archiretiolitinae Subfamily and the Climacograptus longispinus, C. latus, Paraorthograptus pacificus and other diplograptid groups; $2,3,4-$ see $1,2,3$ on fig. 1 . correspondingly.

\section{The supernus event}

Major geological events take place at the Ordovician-Silurian boundary. The Ashgill glaciation and accompanying global climatic cooling and lowering of the sea-level are the most important (Brenchley 1984; Brenchley \& Newall 1984). Orogenic movements of the Taconian phase which occurred approximately at the end of the glaciation have "resulted in structural remodelling of the Protoatlantic and Prototethys oceans" (Tomčzykowa Tomčzyk 1979). These events are reflected in contrasting changes in lithology and faunas (both faunal shift and immigration events), in replacement of anoxic environments by oxic ones (Barnes 1984). Many erosional effects took place in oceanic sediments, within cratonic sequences stratigraphic gaps are well documented. These events have drastically reduced the extent of tropical and subtropical pelagic environments. The areal extent of the black shale sedimentation (anoxic environment) reached its maximum within the supernus Zone. It is almost absent in the extraordinarius Zone. A new expantion of anoxic water masses due to a global transgression starts in some regions in the persculptus Zone, becoming world-wide in the acuminatus Zone.

What are the graptolite dynamics at this time? It is shown at zonal and specific level for most representative sequences - British Isles, Kazakhstan, Northeast USSR and Yangtze Valley (Rickards 1976, Apollonov et al. ed. 1980; Wang et al. 1984; Koren et al. 1983; Stratigraphy 1984). The changes in diversity of syncronous graptolite assemblages are approximately the same for the three curves. Only a curve showing Yangtze Val- 
ley graptolite changes is marked by unusually abundant graptolite associations. Two approximately equal diversity peaks at the pacificus and atavus/vesiculosus zones ( 25 to 35 taxa) is a common feature of all the sections discussed. The extraordinarius-persculptus diversity drop represents one of the most dramatic events in graptolite history.

Mass extinction of Ashgill taxa within the pacificus subzone can be illustrated by the zonal assemblage structure (Fig. 2). Only three diplograptid species survive at the extraordinarius boundary. Many important Ordovician lineages became extinct during this interval. Among them are: all the genera belonging to the Dicranograptidae, Nemagraptidae and Leptograptidae Families, as well as Archiretiolitinae Subfamily. Some Ordovician morphological relicts were recently reported from the Llandovery of China (Stratigraphy...1984). Diplograptid faunas undergo a great crisis as exhibited by the extinction of the Climacograptus species groups, Paraorthograptus, Glyptograptus, and other genera. The strongly impoverished the extraordinarius and persculptus zonal assemblages are represented by simple, non-specialised diplograptids all over the world (Koren 1983; Koren \& Nikitin 1983). It was a time of pronounced deterioration of graptolite habitats. Nevertheless the most important evolutionary novelty - the origin of the uniserial monograptid colony - was introduced in persculptus time (Rickards \& Hutt, 1970). The succeeding acuminatus Zone is characterized by the radiation in surviving diplograptid stocks. It is marked by the appearance and subsequent differentiation in new lineages represented by $\mathrm{Aki}$ -

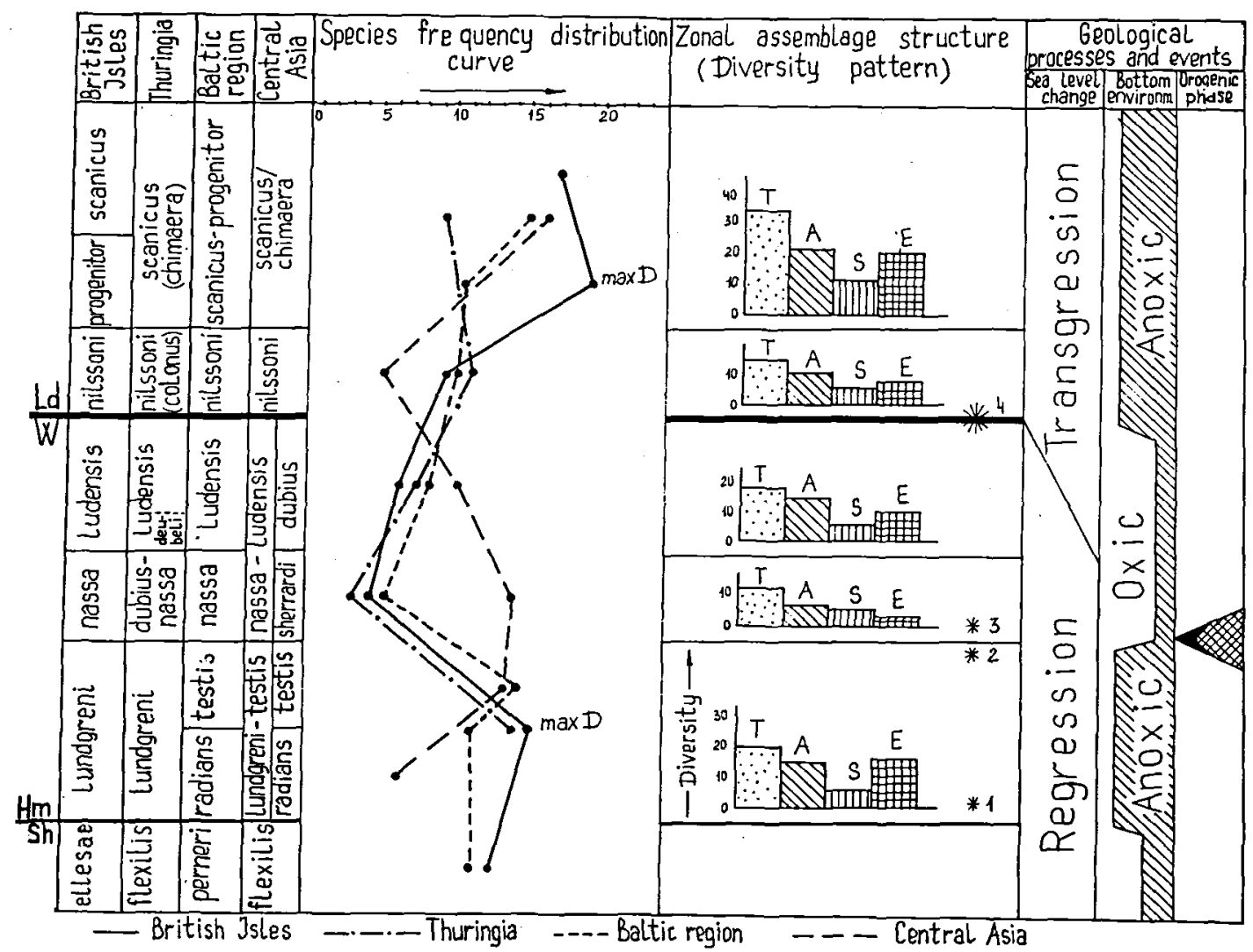

Fig. 3. Graptolite dynamics within the Wenlock - Ludlow boundary interval (the lundgreni event). Abbreviations are the same as in figs. 2 and 4. Asterisks shows the following bioevents: 1 - radiation within the Late Wenlock cyrtograptid stock; 2 - origin of a common pristiograptid ancestor of the Linograptinae, Cucullograptinae and Neocucullograptinae Subfamilies; 3 - radiation of plectograptids and pristiograptids of the Pristiograptus dubius group; 4 - see 10 in fig. 1. 
dograptus, Parakidograptus, Cystograptus, Pseudoclimacograptus and other genera (Rickards et al. 1977). The total number of species becomes twice as large, but most of new developing genera and species are short-lived and in general do not leave any descendents. Half of the zonal taxa become extinct by the atavus base.

The first radiation phase, predominantly within the newly formed monograptids of the Atavograptus stock, begins from the atavus or vesiculosus Zone and reaches its culmination during the triangulatus interval. Many origination events are known for synchronously developing diplograptid lineages (Dimorphograptus, Raphidograptus and others (Rickards et al. 1977).

The most dramatic evolutionary highs and lows can be interrelated through the long and complex chain of events with oceanographic and climatic changes well documented in sedimentary records on a global scale. Among them surface water cooling, changes in distribution of anoxic environments and level of carbonate compensation are of primarily importance. The above events gave rise to profound biofacies changes and strong reduction of the amount of habitats.

\section{The lundgreni event}

The Middle-Late Wenlock regression was gradual, but world-wide detactable. It had a least two maxima almost coinciding with the flexilis and nassa zones. The first level is characterized by the maximum of reef building, the second witnessed and extensive shallowing of cratonic seas and origination of widespread lagoonal facies. The geographical extent of anoxic environment strongly decreases as exhibited by black shale sedimentation except for the lundgreni Zone while extensive oxic environments were favourable for benthic fauna. The nilssoni shale transgression has brought about anoxic conditions with the last Silurian maximum within the scanicus/chimaera Zone.

The lithofacies changes at the Wenlock/Ludlow boundary in the caledonids (Prototethys; Tomčzykowa Tomčzyk 1979) and over the other territories (Central Asia, Canada) are partly attributed to the orogenic phase.
Regional biozonations for the British Isles, Thuringia, East Baltic and Central Asia were chosen (Rickards 1976; Jaeger 1959; Kaljo et al. 1984; Koren, Rinenberg, unpublished data). They represent the outer shelf (slope) and oceanic facies. All the section are fairly complete and contain abundant graptolites. Three species frequency curves except for Central Asia (the Peshkaut section in South Fergana, unpublished data by Koren and Rinenberg) show a well pronounced evolutionary low at the nassa-ludensis and two diversity peaks for the lundgreni and scanicus/chimaera zones. A greater number of species in the nassa-ludensis Zone at the Peshkaut section in South Fergana reflect the radiation of the plectograptid lineages (Gothograptus, Plectograptus, Holoretiolites, Spinograptus). A drastic decrease of monograptid diversity ( 3 to 5 species) is similar in all the section discussed.

This time witnessed an abrupt termination of many Early Silurian lineages. The disappearance of the Cyrtograptinae subfamily marked by maximum diversity in the lundgreni Zone is the taxonomically most important. The lundgreni event of mass extinction' strongly affected the composition of subsequent graptolite assemblages and the evolutionary trends of Ludlow monograptids as well. The disappearance of the Monograptus priodon and Monoclimacis stocks was also a very important phylogenetic event. Morphologically conservative and long-lived pristiograptid stock represented by Pristiograptus dubius (Suess) was subject to quite the opposite effect. There occur some speciation events resulting in appearance of Pristiograptus deubeli (Jaeger), $P$. jaegeri Holl. et al. and others. This was marked by the origination of some new apertural thecal structure paired lateral lobes which progressively evolved and dominate among the other apertural structures of the Late Ludlow monograptids. The origination of a new important Monograptus ludensis linage is most probably related to the $P$. $d u$ bius group. An even more phylogenetically important biological event is the appearance of the common predecessor for the Ludlow the Linograptinae, Cucullograptina and Neocucullograptinae Subfamilies which starts to develop at the lundgreni/nassa boundary. The cucullograptid radiation begins within "stem" lobograptids in the early scanicus/chimaera Zone and reaches a maximum at the end of it. 
The total number of species after well pronounced drop in the nassa Zone slowly increase with the advance of the Early Ludlow transgression. Variable adaptive thecal apertural structures not long developed, reached a culmination in the scanicus/chimaera Zone. A relatively high proportion of taxa extinction characterizes each early Ludlow graptolite Zone.

The summary of the data shown leads to the following conclusion. The easily discernible large-scale abiotic and biotic environmental changes within the pelagic realm between the lundgreni and scanicus levels were of great ecological and phylogenetic significance for graptolite evolution. It is noteworthy that benthic groups were not greatly affected by the above changes. Late Silurian graptolites have never reached the earlier diversity in morphological structures. Since the beginning of the Ludlow graptolites tried new adaptive paths some of which persisted till the end of Silurian, but most of them were successful only for a short while.

\section{The leintwardinensis event}

There are only a few complete Upper Ludlow sections with continuous graptolite succession. In general, the Late Silurian is characterized by the regressive trend of sedimentation. Only the scanicus/chimaera and formosus/spineus zones suggest the distribution of transgressive anoxic water masses resulted in the black shale sedimentation reported from some regions. The environmental changes are well documented by the detectable lithoevents within graptolite sequences approximately beginning with the leintwardinensis Zone. These major events were mainly marked by an

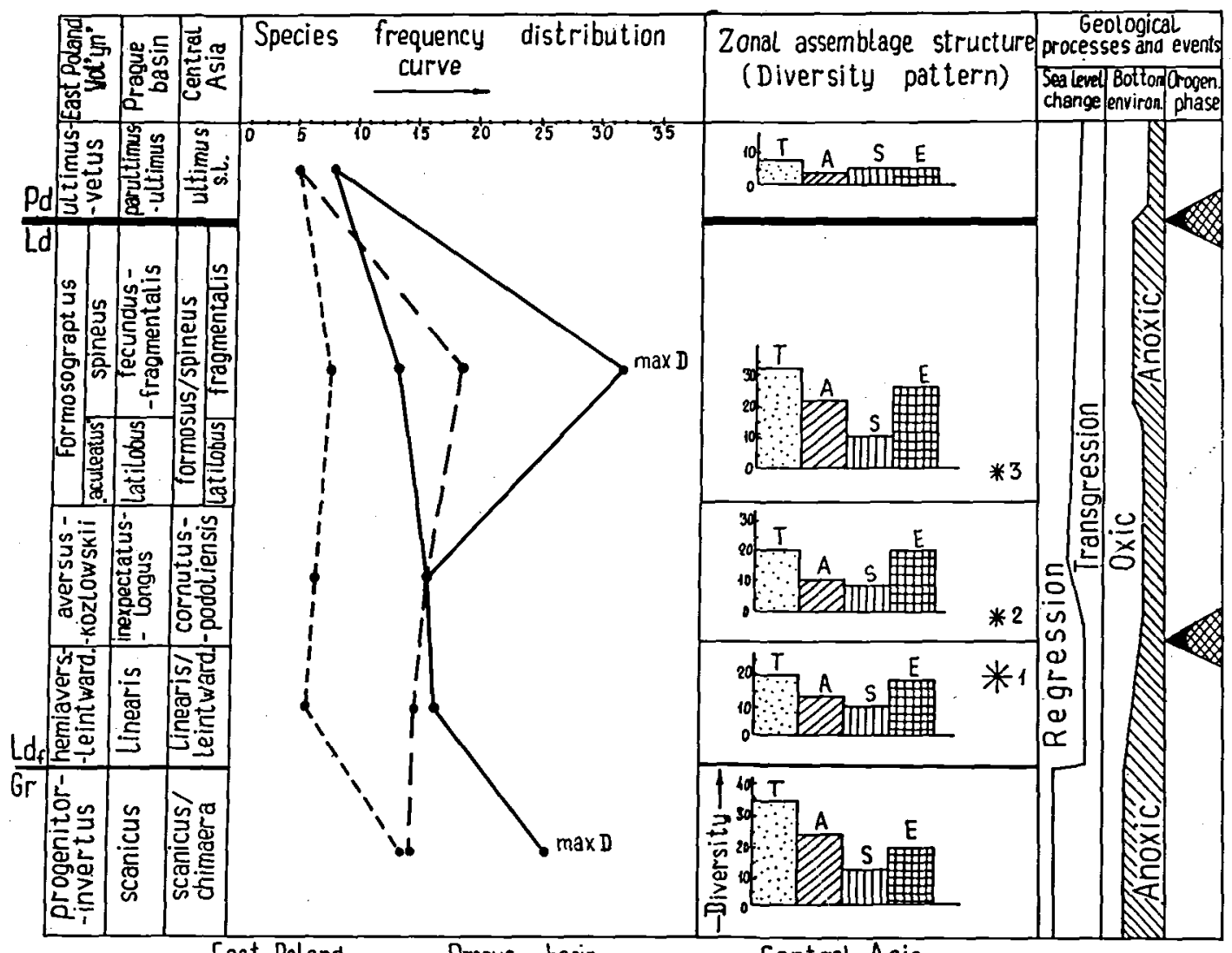

-East Poland ---Prague basin - - Central Asia

Fig. 4. Graptolite dynamics in Late Ludfordian - Early Pridoli time (the leintwardinensis event). Asteriscs show the following bioevents: 1,2,3 - see 11,12,13 on fig. 1 correspondingly. Abbreviation for series and stages; Ash - Ashgill, Ln - Llandovery, W - Welock, Ld - Ludlow, Pd - Pridoli, Lch - Lochkov, Pg - Pragian, Sh - Sheinwoodian, Hm - Homerian, Gr - Gorstian, Ldf - Ludfordian. 
extensive carbonate sedimentation and rich benthic fauna. This implies the oxygenation of bottom waters and rapid biofacies shift. They may be connected with Late Caledonian orogenic movements within the Prototethys and the Protoatlantic. The cessation of graptolite shale sedimentation in Britain and Balto-Scandia in the leintwardinensis - bohemicus zones is probably one of the first consequences. Litho- and biofacies shift in slope environments is reflected in replacement of dark graptolite shales by cephalopode limestones (Barrandian, Marocco, Sardinia; Jaeger 1976). In the deeper basin and oceanic environments so called Ockerkalk or grey-greenish shale sedimentation have interrupted the graptolite-bearing sequences (Carnic Alps, Thuringia). The onset of deep-water carbonates falls at the scanicus/leintwardinensis boundary. They continue the section until the transgrediens Zone of the late Pridoli. Jaeger (1976, S. 278) considers this type of sediments as typical of the Prototethys and its margins. However, the author has recently found similar deep-water carbonates of the same age within the graptolite successions in the Polar Urals, Pai-Khoi and Central Asia. Their distribution in different palaeobasins suggests sedimentation in similar oceanic environments which are probably characterized by the low level of carbonate sedimentation and seafloor scour. In the terminology introduced by Walliser $(1984 \mathrm{a}, \mathrm{b})$ they can be considered as the time-specific facies for the Late Silurian. As a result of facial reconstructions the habitats have strongly decreased judging from the limited number of graptolite occurrences. Within those biotopes which continued to exist some abiotic and biotic changes took place. A new phase of constractive morphological changes evidences new graptolite adaptive trends.

The sections chosen provide good examples of different pelagic facies - deep-shelf environments of marginal sea (East Polan, Volyn) and similar conditions within geosynclinal Prague Basin and the oceanic black shale sedimentation in South Fergana. The studies on graptolites and biozonations made by A. Urbanek, P. D. Tsegelnjuk, A. Pribyl, R. E. Rinenberg and the author are still in progress. At present the data about graptolite dynamics within the leintwardinensis to ultimus s.l. zones are far from being complete. This is examplified by species frequency curve (Fig. 4).
The left curve, plotted for the Prague Basin, seems to be quite smooth. That is possibly due to the poor or inadequate data about the Kopanina beds graptolites. There is a compound curve for East Poland and Volyn. The frequency of species for the scanicus/chimaera to leintwardinensis zones is based on the Urbarek's data (1966, 1970). For the formosus/spineus level two degrees of diversity are shown: one (13) shows the number of species in the Melnik borehole recognised by A. Urbanek (oral communication, 1985), the other (32) are from numerous boreholes of Volyn determined by Tsegelnjuk (1981; The Silurian... 1983). The latter extremely high magnitude can at least partly be attributed to an artificial taxonomic splitting. The frequency curve for the Peshkaut section reflects evidence obtained from the continuous sequence of black shales and limestones similar to Ockerkalk with frequent graptolite events. The curve shows the number of taxa which can be recognized on the basis of flattened but well preserved material.

The general picture of the diversity pattern is as follows. The number of species per zone is approximately the same. However, the zonal assemblage structure allows us to conclude that graptolite dynamics were not even. The number of surviving taxa per zone is more or less constant. They consist of saetograptids (the scanicus/ chimaera and leintwardinensis zones), pristiograptids and bohemograptids (the scanicus/chimaera to formosus/spineus zones).

The diagrams show a distinct renovation in the composition of the Late Ludlow fauna within each zone. So, almost all lobograptids disappear in the lower zone. The earlier abundant cucullograptids, saetograptids and plectograptids disappear in the two subsequent units. The next wave of mass extinction is related to the end of the formosus/spineus Zone. In extent the event may be compared to that of the supernus Zone close to the Ordovician/Silurian boundary.

The major evolutionary events reflected in the appearance of adaptive morphological structures of high taxonomic rank can be assigned to the end of the leintwardinensis and beginning of the cornutus zones. The most important among them are: 1. an appearance of Linograptus able to produce numerous sicula cladia and 2. splitting of bohemograptid lineage and origination of specialized Neolobograptus - a possible neocucul- 
lograptid ancestor whose phyletic evolution is typical of subsequent zonal phases (cornutus to kozlowskii; Urbanek, 1966, 1970). Another important phylogenetic event is that of the formosus/spineus Zone when the diversification of monograptids takes place and promotes several new lineages (Tsegelnjuk, 1976, 1981). Several new specialized monograptids with apertural structures not seen since Llandovery, appear at the same time. For the last time the morphological and taxonomical diversity of Late Silurian graptolites reaches a maximum of a size which can be compared to that of the scanicus/chimaera zonal assemblage.

\section{Conclusions}

To obtain a general idea about the dynamics of Silurian and Lower Devonian graptolites major extinction-origination events within the standard graptolite zonation have been outlined (Fig. 1).

The graptolite evolution during the time of monograptid existance is subdivided into three phases using a comparison of the amplitude of extinction and origination of taxa and the closeness of successive cycles.

The first phase is related to the LlandoveryEarly Wenlock transgression marking the maximal spatial distribution of black-shale graptolite facies. Following the mass extinction event at the supernus Zone, the time of glaciation maximum, diplograptids and monograptids become first gradually and then abruptly very diverse. The most prominent Silurian peak is assigned to the triangulatus Zone when several syncronous and succeding radiation events in already numerous lineages took place. The number of species totals 50 to 70 . Graptolite dynamics in the Middle to Late Llandovery is more or less regular and persistant. The fauna is slowly loosing its high diversity when in Early Wenlock time (the riccartonensis Zone) another mass extinction event took place.

The second Late Silurian phase (the ellesae to transgrediens zones) is a time of unstable abiotic environments. Eustatic transgressive and regressive sedimentation cycles, orogenic phases, alternation of anoxic and oxic environments, fluctuation in carbonate sedimentation depth, distribution of lime-rich water masses, and other causes were responsible for frequent deteriorations and formations of new graptolite habitat or microhabitats. The areal extent of graptolite facies is markedly reduce. The complex genetic relations made the dynamics of Late Silurian graptolites extremely uneven and jerky. Frequent waves of extinction-origination events (Fig. 1) demonstrate that the ecological homeostasis of graptolites is disturbed. There are stille several attempts to occupy new or existing ecological niches at introductions of new morphological structures, some of them prove to be successful for a while. The Early and Late Ludlow graptolites show two well pronounced diversity peaks. Another but smaller diversity maximum falls in the Middle Pridoli before the extinction of the most Silurian stocks.

During the third phase in graptolite evolution, that is during the Early Devonian, graptolites are characterised by an exclusively monotonous morphological thecal structure and very simple rhabdosomes. The last step in the adaptivity pattern is the appearance of a short-lived Abiesgraptus, which was able to produce both sicular and thecal cladia. However, the multistiped rhabdosomes became completely extinct by the end of the Lochkov. Since then evolution followed a phyletic speciation trend in some single lineages of uncinate monograptids. The uniformis and yukonensis zones are marked by relative high diversity (8 to 9 taxa).

The final extinction of the remaining 4 to 5 species took place during a global Early Devonian transgression which brings about an extensive distribution of anoxic water masses as evidenced from sedimentary controls. Previously such effects supposedly were related to periods of graptolite diversification. So, we may suggest that the extinction of the group was strongly affected by peculiar biotic factors, primarily it may have been the break in trophic chains.

Acknowledgements. For discussion and helpful ideas I am grateful to Adam Urbanek and Otto Walliser. Barry Rickards kindly improved the English version of the manuscript.

\section{Dansk sammendrag}

På grundlag af allerede eksisterende biostratigrafiske data forsøges det $i$ afhandlingen at vurdere dynamikken $i$ graptolit evolutionen som afspejlet $i$ pelagiske aflejringer fra silur og tidlig devon. I de udvalgte tidsafsnit er uddøen og fremkomsten af 
nye former af interesse. Disse ændringer er delvist forbundet med miljømæssige faktorer $i$ forbindelse med eustatiske havniveau-andringer og klimatiske skift, skift $i$ anoxsiske betingelser, forskydning af cabonat-sedimentationen i en mere pelagisk retning samt af andre globalt mærkbare ændringer.

\section{References}

Apollonov, M. K., Bandaletov, S. M. and Nikitin, I. F. (eds.) 1980: The Ordovician and Silurian boundary in Kazakhstan. Alma-Ata, $299 \mathrm{pp}$.

Barnes, Ch. 1984: Global ecosystem change across the Ordovician-Silurian boundary revealed by conodont data. $A b$. stracts of the 27th IGC, 1, sections 01 to 03, Moscow, "Nauka", 18-19.

Bassett, M. G. 1985: Towards a "common language" in stratigraphy. Episodes, 8, 87-92.

Berry, W. B. N. 1973: Silurian-Early Devonian graptolites. In: Hallam, A. (ed.) Atlas of Palaeobiogeography, 81-87, Amsterdam, London, New York.

Berry, W. B. N. 1979: Graptolite biogeography: A biogeography of some lower Paleozoic Plankton. In Gray, J. and Boucot, A. J. (eds.) Historical biogeography, plate tectonics and the changing environment. Oregon State University Press, 105-115.

Berry, W. B. N. 1984. Black shale geochemistry: A possible guide to Ordovician water masses. In Bruton, D. L. (ed.) Aspects of the Ordovician System. 177-181. Palaeontol. Contrib. University of Oslo. 295, Universitetsforlaget.

Berry, W. B. N. and Boucot, A. J. 1972. Silurian Graptolite depth zonation. Intern. Geol. Congress, 24th session, section 7, 59-66, Montreal.

Berry, W. B. N. and Wilde, P., 1978: Progressive ventilation of the oceans - an explanation for the distribution of the Lower Paleozoic black shales. Amer. J. Sci., 278, 257-275.

Berry, W. B. N. and Wilde, P. 1983: Evolutionary and geologic consequences of organic carbon fixing in the primitive anoxic ocean. Geology, 11, 141-145.

Brenchley, P. J. 1984: Late Ordovician Extinctions and their Relationship to the Gondwana Glaciation. In Brenchley, P. J. (ed.). Fossils and Climate. John Wiley \& Sons Ltd. 291-315.

Brenchley, P. J. and Newall, G. 1984: Late Ordovician environmental changes and their effect on faunas. In Bruton, D. L. (ed.) Aspects of the Ordovician System. 65-79. Palaeontol. Contrib. University of Oslo, 295, Universitetforlaget.

Bulman, O. M. B. 1964: Lower Paleozoic plankton. Quart. J. Geol. Soc. London. 120, 455-476.

Bulman, O. M. B. 1971: Graptolite faunal distribution. In: Middlemiss, F. A., Rawson, P. F. and Newall, G. (eds.) Faunal Provinces in space and time. Geol. J. Special Issue, $4,47-60$.

Carter, C., Trexler, J. H. and Churkin, M., Jr. 1980: Dating of graptolite zones by sedimentation rates: implications for rates of evolution. Lethaia, 13, 279-287, Oslo.

Churkin, M. Jr., Carter, C. and Johnson, B. R. 1977: Subdivision of Ordovician and Silurian time scale using accumulation rates of graptolite shale. Geology 5, 452-456.

Harland, W. B., Cox, A. V., Llewellin, P. G., Picton, C. A. G., Smith, A. G. and Watters, R. 1982: A geological time scale. Cambridge University Press, pp. 131.

Holland, Ch. H. 1984: Steps to a standard Silurian. Proceed. of the 27th $I G C, 1,127-156$, Stratigraphy VNU science Press, Utrecht.

Holland, Ch. H. 1985: Series and stages of the Silurian System. Episodes 8, 101-103.
Erdtmann, B.-D. 1976: Ecostratigraphy of Ordovician graptoloids. In: Bassett, M. G. (ed.). The Ordovician System. Proceed. of Palaeont. Assoc. Symposium, Birmingham, 621-643. University of Wales Press and National Museum of Wales, Cardiff

Jaeger, H. 1959: Graptolithen und Stratigraphic des jüngsten Thüringisher Silurs. Abh. Acad. Wiss. DDR zu Berlin, Jh. 1959, 2, S, 191.

Jaeger, H. 1976: Das Silur und Unterdevon vom thüringischen Typ in Sardinien und seine regionalgeologische Bedeutung. Nova Acta Leopold. Abh. Akad. DDR Naturforscher Leopoldina. Neue Folge. N224, 45, 263-299.

Jaeger, H. 1978: Late graptoloid faunas and the problem of graptoloid extinction. Acta Palaeont. Pol., 23, 4, 497-521.

Kaljo, D. 1978: On the bathymetric distribution of graptolites. Acta Palaeont. Pol., 23, 4, 523-531.

Kaljo, D., Pashkevichus, J. and Ulst, R, 1984: Silurian Graptolite zones of East Baltic Region. In: Stratigrafia drevnepaleozojskikh otlojenij Pribaltiki. Tallinn, 94-118.

Kirk, N. H. 1969: Some thoughts on the ecology, mode of life and evolution of the Graptolithina. Proceed. geol. Soc. London, 1659, 272-292.

Kirk, N. H. 1972: More thoughts on the automobility of the graptolites. J. geol Soc., 128, N2, 127-133.

Koren, T. N. 1979: Late monograptid faunas and the problem of graptolite extinction. Acta Palaeont. Pol, 24, 1, 79-106.

Koren, T. N. 1982: Problems of graptolite zonation of the Upper Silurian Series. In: Sovremennoe znachenie paleontologii dlja stratigrafii. 24 sessii Vses. Paleont. obsch. Leningrad, "Nauka", 43-50.

Koren, T. N. 1983: Lower boundary of the Silurian System and problem of its definition. Sov. Geologia, 2, 56-67.

Koren, T. N. 1984: Graptolite zones and standard stratigraphic scale of the Silurian. In: Proceed. of the 27th IGC, 1 , 47-76, Stratigraphy, VNU Science Press, Utrecht.

Koren, T. and Nikitjn, I. 1983: Comments on the definition of the Ordovician-Silurian boundary. Eesti NSV Teaduste Akad. Toimetised. 32. Koide Geologia 3, 96-100.

Koren, T. N., Oradovskaya, M. M., Pylma, L. J., Sobolevskaya, R. F. and Chugaeva, M. N. 1983: The Ordovician and Silurian boundary in the Northeast of the USSR. Leningrad. "Nauka", pp. 205.

Koren, T. N. and Rickards, R. B. 1979: Extinction of the graptolites. In: Harris, A. L., Holland, Ch. H. and Leake, B. E. (eds.) The caledonids of the British Isles-Reviewed. Scottish Acad. Press, Edinburg, 457-466.

Lenz, A. C. and Chen, Xu 1985: Graptolite distribution and lithofacies some case histories. J. Paleontology, 59, 636642 .

Prrinyl, A. 1983: Graptolite biozones of the Kopanina and Pridoli Formations in the Upper Silurian of Central Bohemia. Cas. pro mineral. a geologii, 28, 149-167.

Rickards, R. B. 1975: Palaeoecology of the Graptolithina, an extinct class of the phylum Hemichordata. Biol. Revs. Cambridge Phil. Soc., 50, N4, 397-436.

Rickards, R. B. 1976: The sequence of Silurian graptolite zones in the British Isles. Geol. $J, 11,153-188$.

Rickards, R. B. 1978: Major aspects of evolution of the graptolites. Acta Palaeont. Pol., 23, 585-594.

Rickards, R. B. and Hutt, J. E. 1970: The earliest monograptid. Proc. geol. Soc. London, 1663, 115-119.

Rickards, R. B., Hutt, J. E. and Berry, W. B. N. 1977: Evolution of the Silurian and Devonian graptoloids. Bull. Brit. Mus. (Natur. Hist.) Geol., 28, pp. 120.

Skevington, D. 1974: Controls influencing the composition and distribution of Ordovician graptolite faunal provinces. $I n$ : Rickards, R. B., Jackson, D. E. and Hughes, C. P. (eds.) Graptolite studies in honour of Bulman O.M.B. Spec. Pap. Palaeont., 13, 59-74. 
platform. In: Paleontologia i stratigrafia verkhnego kembria i niznego paleozoya yugozapada Vost.-Evrop. platformy. 91-132. Naukova Dumka, Kiev.

Tsegelnjuk, P. D. 1981: Silurian biochronology in Volyno-Podolia. Preprint IGN AN USSR 81-26, $56 \mathrm{pp}$.

The Silurian of Podolia. The guide to excursion 1983: Kiev. Naukova Dumka, pp. 222.

Urbanek, A. 1966: On the morphology and evolution of the Cucullograptinae (Monograptidae, Graptolithina). Acta Palaeont. Pol., 11, 292-519.

Urbanek, A. 1970: Neocucullograptinae n.subfam. (Graptolithina) - their evolutionary and stratigraphic bearing. Acta Palaeont. Pol., 15, 393.

Walliser, O. H. 1984a: Geological processes and global events. E. U. G. Conference Reports, Terra cognita, 4, 17-20.

Walliser, O. H. 1984b: Global events, event-stratigraphy and "chronostratigraphy" within the Phanerozoic. Abstracts of 27th IGC, 1, section 01 to 03, Moscow, "Nauka", 208.

Walliser, O. H. 1984c: Global events and evolution. In: Proceed. of the 27th IGC, 2, Paleontology, VNU Sci. Press, Utrecht.

Wang Xiaofeng, Zeng Qinglua, Zhou Tianmei, Ni Shizhao, Xu Guanghong and Li Zhihong 1984: Ordovician-Silurian boundary biostratigraphy of Eastern Yangtze Gorges, China. Scientia Sinica (Ser. B), 27, 101-111.

Watkins, R. and Berry, W. B. N. 1977: Ecology of a Late Silurian fauna of graptolites and associated organisms. Lethaia, 10, 267-286, Osio.

Williams, S. H. and Rickards, R. B. 1984: Palaeoecology of graptolitic black shales. In: Bruton, D. L. (ed.) Aspects of the Ordovician System. 159-166, Palaeont. Contrib. University of $O_{\text {slo, }} 295$, Universitetforlaget.

Stratigraphy and palaeontology of Systemic boundaries in China. Ordovician-Silurian boundary. Compiled by Nanjing Institute of Geology and Palacontol. Acad. Sinica. Anhui Sci. and Technology Publishing House, pp. 516.

Sudbury, M. 1958: Triangulate monograptids from the Monograptus gregarius Zone (Lower Llandovery) of the Rheidol Gorge (Cardiganshire) Phil. Trans. R. Soc. (B), 241, 485 .

Tomžzykowa, E. and Tomczyk, H. 1979: Stratigraphy of the Polish Silurian and Lower Devonian and development of the Proro-Tethys. Acta Palaeont. Pol., 24, 165-183.

Tsegelnjuk, P. D. 1976: Posdnesilurijskie i rannedevonskie monograptidy yugo-zapadnoj okrainy Vostochno-evropejskoj platformy. Late Silurian and Early Devonian monograptids of the southwestern margin of East-European 